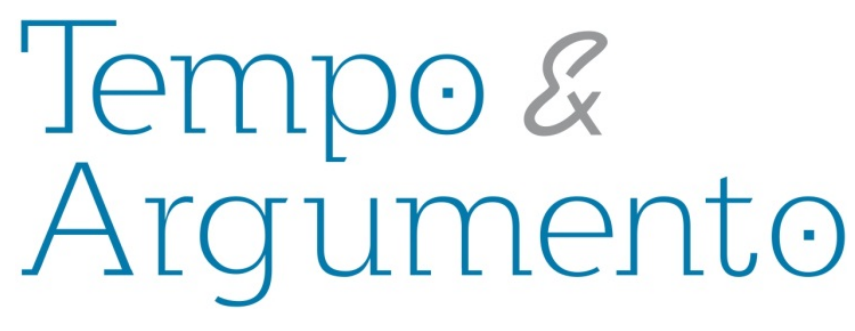

\title{
Os debates em torno da ilegalidade do aborto: da luta pela autonomia reprodutiva feminina à esfera legal dos projetos de leis
}

\begin{abstract}
Resumo
Desde a década de 1990, o aborto inseguro é considerado um grave problema de saúde pública pelas comunidades internacionais como Organização das Nações Unidas (ONU) e Organização Mundial de Saúde (OMS). No Brasil, a sua prática se mostra também insegura devido às condições precárias tanto por falta de capacitação de pessoas e de ambientes inadequados sem os padrões de higiene mínimos para prática. Assim, o aborto realizado de forma insegura causa sequelas à saúde e até óbitos em mulheres, danos gerados, principalmente, por sua ilegalidade imposta judicialmente. Observa-se que na discussão sobre a ilegalidade do aborto ocorre uma mobilização daqueles que lutam pela manutenção da sua criminalização e ilegalidade e outros que lutam pela sua descriminalização e legalização como grupos feministas e de mulheres e setores governamentais, nos quais muitos resultam em projetos de leis. É interessante frisar que ao logo do tempo, os projetos que tocam a temática aborto foram aumentando progressivamente; alguns deles ganharam mais destaque que outros como o presente estudo aqui os descrevem. Debates reacendidos recentemente com o projeto de lei 478/2007 - "bolsa estupro" que traz o aborto novamente em pauta. Devese, ainda, ressaltar que o debate sobre a prática abortiva tanto na luta pela autonomia reprodutiva feminina como na esfera legal revelam elementos importantes para se pensar as relações de gênero como: a percepção do feminino na sociedade brasileira, a disputada de poderes discursivos pelo controle do corpo feminino, o poder decisório das mulheres em abortar ou não, além da condenação moral sobre as que praticam.
\end{abstract}

Palavras-chave: Ilegalidade; Aborto inseguro; Saúde reprodutiva.
Luiz Augusto Mugnai Vieira Júnior Graduado em Ciencias Socias pela Univerisdade Estadual de Londrina (UEL - PR). Mestre de História, Poder e Práticas Sociais da Universidade Estadual do Oeste do Paraná (UNIOESTE- PR). Professor da Universidade Paranaense (UNIPAR-PR) gutomugnai@hotmail.com

\footnotetext{
Para citar este artigo:

VIEIRA JÚNIOR, Luiz Augusto Mugnai. Os debates em torno da ilegalidade do aborto: da luta pela autonomia reprodutiva feminina à esfera legal dos projetos de leis. Revista Tempo e Argumento, Florianópolis, v. 6, n. 11, p. 423-460, jan./abr. 2014.
}

DOI: $10.5965 / 2175180306112014423$

http: //dx.doi.org/10.5965/2175180306112014423 


\title{
Discussions around unlawfulness abortion: the struggle for female reproductive autonomy to legal sphere of draft laws
}

\begin{abstract}
Since the 1990, unsafe abortion is considered a serious public health problem by the international community as the United Nations (UN) and the World Health Organization (who). In Brazil, its practice is also insecure due to precarious conditions both for lack of empowerment of people and inadequate environment without the minimum hygiene standards for practice. Thus abortion performed Unsafely health sequel and even cause deaths in women, damage generated mainly by its illegality imposed judicially. It is observed that in the discussion about the illegality of abortion occurs a mobilization of those fighting for the maintenance of its criminalization and illegality and others who fight for its decriminalization and legalization as feminist groups and women and Government sectors in which many result in bills. It is interesting to note that over time, the projects that touch the abortion issue were increasing steadily, some of them won more highlights than others as the present study here describe them. Discussions rekindled recently with Bill 478/2007-"rape bonus" that brings the abortion on the agenda again. Must also point out that the debate on abortion practice both in the struggle for female reproductive autonomy as in legal sphere reveal important elements to think about gender relations as: the perception of women in Brazilian society, the disputed discursive powers for control of the female body, the decision-making power of women to abort or not, beyond moral condemnation on those who practice.
\end{abstract}

Keywords: Illegality; Unsafe abortion; Reproductive health. 


\section{Introdução}

Os embates do tempo presente em relação à prática abortiva são gerados pelo questionamento da ilegalidade desta no Brasil. Observa-se que parte de tal questão está presente nas lutas das mulheres que têm atravessado ao longo da história e, agora ampliada, ocupam espaços políticos como na esfera legal dos projetos de leis. Ou seja, questionamento da atual legislação em relação ao aborto no Brasil que ocorre por parte dos movimentos de mulheres no âmbito dos direitos reprodutivos, por isso, questionam a legislação restritiva brasileira, o Código Penal de 1940 que estabelece, em seu artigo $\mathrm{n}^{\circ}$ 126, os casos em que é permitido o aborto legal: estupro e risco de morte para a mulher.

O presente artigo tem como proposta discutir as lutas das mulheres em relação à prática abortiva pela autonomia dos seus corpos no direito reprodutivo e na esfera legal de projetos que tangem o aborto a partir da década de noventa, período no qual que se inicia efetivamente a tramitação dos projetos de lei sobre o teor da sua ilegalidade. A luta das mulheres, especialmente as lutas feministas no Brasil trazem à tona esses conflitos por considerarem o aborto como um exercício de autonomia reprodutiva das mulheres. Propõe-se aqui "resgatar" quando e como o aborto aparece na luta das mulheres no Brasil e quais são os segmentos que apóiam a legalidade do aborto reivindicando-o como uma questão de autonomia reprodutiva. ${ }^{1}$

Observa-se que essa luta das mulheres pelo o direito de decidir abortar traz outro embate do tempo presente em relação à prática abortiva: a luta em torno da manutenção da criminalização ou pela descriminalização parcial ou total do aborto. Essa disputa se mostra localizada na esfera legal por meio da apresentação de diversos projetos de lei que visam ora a descriminalização do aborto e ora, alguns outros projetos contrários lutam, pela criminalização da prática. Enfim, projetos de leis que encontram em luta travada em torno da mobilização pela descriminalização e criminalização do aborto na esfera legal no Brasil. Além daqueles projetos que são classificados neutros, os

\footnotetext{
Os textos aqui referenciados do Centro Feminista de Estudo e Assessoria - CFMEA são aqueles considerados como os mais significativos sobre o tema do aborto. Muitos destes textos não tem autoria específica, o que pressupõe-se, enunciem a perspectiva do órgão sobre o tema. Se houver autoria esta será referida.
} 
quais apesar de tratarem sobre o aborto, se posicionam neutramente quanto à criminalização e descriminalização da sua prática.

\section{A luta e o movimento das mulheres no Brasil pela autonomia reprodutiva}

Sabe-se que os movimentos de mulheres e os movimentos feministas não são algo peculiar do Brasil e sim do mundo ocidental ${ }^{2}$. Frente a isso não temos a intenção aqui de fazer uma trajetória ou uma história desses movimentos no Brasil ${ }^{3}$, e sim apontar alguns aspectos importantes para perceber a luta das mulheres pela autonomia reprodutiva na contemporaneidade. Observa-se que na trajetória do movimento feminista, como evidencia tanto Scavone (2000) como Pedro (2003), existem tanto recuos quanto avanços na questão do aborto quando esse emerge como pauta no movimento feminista brasileiro. Na transição democrática, o aborto é mencionado de forma tímida devido à ação da ditadura e da Igreja nos mores sociais. Segundo Scavone, é na democratização dos sistemas políticos que há uma centralidade de temas como contracepção e legalização do aborto em uma noção de direitos reprodutivos.

A luta das mulheres por mudanças está presente na organização coletiva dos movimentos sociais, além do esforço individual da mulher nos mais diversos âmbitos sociais, desde, por exemplo, o acesso ao mercado de trabalho assalariado e à educação de qualidade, como também pelos direitos de autonomia reprodutiva. As mulheres têmse feito presentes em vários movimentos que têm como objetivos melhores condições de vida, dentre eles destacam-se as lutas camponesas, os movimentos urbanos, como os movimentos negros, indígenas, homossexuais e transgêneros. Dessa forma, as mulheres "têm se organizado na luta contra a violência que as mulheres sofrem por serem mulheres, na reivindicação por saúde da mulher, creches, e nos últimos anos, por maior participação nos espaços de poder e decisão." (FARIA, 2005, p.18).

\footnotetext{
${ }^{2}$ Ver a coletânea de cinco volumes organizada por PERROT, Michelle; DUBY, Georges. História das Mulheres no Ocidente. Porto: Afrontamento, 1991.

${ }^{3}$ Ver também os livros de: PRIORE, Mary Del. (Org.). História das mulheres no Brasil. São Paulo: Contexto, 2001; PINTO, Céli Regina J. Uma História do Feminismo no Brasil. São Paulo: Perseu Abramo, 2003.
} 
Para compreender a luta das mulheres ${ }^{4}$, em especial das feministas do Brasil, fazse necessário compreender brevemente alguns marcos do movimento:

Um marco fundamental na história dos movimentos de mulheres em todo o mundo foi o ano de 1975, declarado pela ONU como o Ano Internacional da Mulher. Neste ano realizou-se a $1^{\text {a }}$ Conferência Mundial sobre a Mulher, sendo declarada a Década da Mulher - 1975-84. Esta iniciativa significou o reconhecimento de que as mulheres vivenciavam situações de desigualdades e de discriminações e os Governos de todo o mundo assumiram o compromisso de adotar medidas visando mudar esta situação. No Brasil, as mulheres promoveram grandes debates e criaram os primeiros grupos feministas, em São Paulo e no Rio de Janeiro. (CENTRO FEMINISTA DE ESTUDOS E ASSESSORIA, 2010)

O Brasil da década de setenta passou por um período em que as lutas das mulheres por direitos e pela igualdade de gênero foram muito intensas. ${ }^{5}$ Foi também nesse momento que algumas ações políticas promovidas pelo movimento puderam ser percebidas, como o início da campanha "Quem ama não mata" (campanha contra a violência a mulher). Nessa mesma época, as Nações Unidas criaram o Ano Internacional da Mulher como também foi criada uma convenção internacional pela eliminação de todas as formas de discriminação contra a mulher. Finalmente, após uma longa luta pelo divórcio no Brasil, foi aprovada a Lei do Divórcio (Lei 6.515/1977), no final dos anos setenta (CENTRO FEMINISTA DE ESTUDOS E ASSESSORIA, 2006).

Todavia, segundo Scavone (2008), ao observar:

a história dos debates e das ações políticas feministas em prol da liberalização do aborto no País, constatamos que ela foi marcada por avanços, recuos e, sobretudo, por inúmeras negociações políticas. Da omissão da palavra "aborto", em meados dos anos 70 - para assegurar as alianças políticas com os setores da esquerda e da Igreja Católica progressista na luta contra a Ditadura -, à opção política pela descriminalização e pela efetivação dos casos previstos por lei, o

\footnotetext{
${ }^{4}$ Ver tópico "Linha do Tempo" do artigo: CFEMEA. Mulheres reúnem-se pelo fim da violência no DF, 2009. O Centro Feminista de Estudo Feminista é um grupo de mulheres feministas de Brasília, participantes ativas das mobilizações frente à Assembleia Constituinte que contribui para a conquista de direitos importantes para as brasileiras na Constituição Federal de 1988 - dentre eles, a igualdade de direitos e obrigações entre mulheres e homens. A escolha de artigos do CFEMEA se deve por sua referência nacional e regional para os movimentos feministas que almejam a transformação das sociedades latinoamericanas, tão profundamente marcadas por desigualdades sociais de gênero.

5 Entretanto, vale chamar atenção que não havia nas lutas do movimento um pensamento homogêneo, existia no movimento feminista multivisões, posicionamentos que divergiam sobre diversas questões.
} 
percurso das políticas feministas para tratar do problema indica não só o poder das forças conservadoras em jogo como a vocação política do feminismo brasileiro para a negociação. (SCAVONE, 2008, p.676)

No Brasil, até a década de 1970, a sociedade conviveu sem maiores contestações com a lei restritiva à prática do aborto devido à forte influência dos valores religiosos ambientados em uma política ditatorial sobre o corpo social. Foi a emergência do movimento feminista contemporâneo, em sintonia com que acontecia na Europa e nos Estados Unidos, que fez com que o aborto se tornasse um tema cada vez mais evidenciado publicamente. De acordo com Scavone (2008, p. 676) "o feminismo brasileiro já tinha uma posição política sobre o aborto fundamentada no princípio do direito individual." Porém as feministas faziam manobras para não deixar isso muito evidenciado utilizando de fórmulas com "direito de decidir pelo número de filhos desejados", "direito de conhecer e decidir sobre seu próprio corpo", entre outras reivindicações, além de que as próprias feministas, ligadas aos partidos de esquerda ortodoxos não aceitavam enfatizar a questão do aborto como também fazia a Igreja.

Verifica-se que o aborto e a sexualidade apareceram como pautas prioritárias da agenda feminista no Brasil, principalmente a partir da transição do regime militar para o democrático, pois aquele limitava a sua visibilidade nas questões políticas, omitindo assim até a palavra aborto.

As políticas feministas relacionadas ao aborto, principalmente aquelas para liberação de sua prática em sua totalidade, se mostram como um dos grandes desafios da história do feminismo brasileiro contemporâneo. Em percurso a esses desafios, outras lutas foram travadas, discutidas e conquistadas nas décadas seguintes. Essas serão destacadas neste trecho do trabalho assim como apresentam-se comentários sobre a luta pela autonomia reprodutiva.

O debate das questões reprodutivas no Brasil, que ocorre no final dos anos setenta e início dos anos oitenta, tem o direito ao aborto e ao acesso a uma contracepção segura, como centro de discussão. Porém ainda de maneira tímida, devido ao próprio contexto em que a luta das mulheres se encontrava, pois os direitos políticos básicos que haviam sido confiscados pela ditadura militar se mostravam mais urgentes. Entretanto, 

no ano de 1983 possibilitava um olhar integral do corpo da mulher e de todas as fases da reprodução feminina, tornando-se assim algo inédito e progressista em relação às outras políticas públicas que vigoravam até aquele momento. Apesar do movimento feminista naquela época não se utilizar do conceito de direitos reprodutivos, a implantação de tal programa era uma conquista de direitos das mulheres. Assim como a criação e efetivação do PAISM nos serviços públicos de saúde desde o ano de 1984, programa esse que até hoje se mostra mais notório do que de ações realizadas (SCAVONE, 2000).

A noção de direitos reprodutivos obteve uma expansão no movimento feminista mundial por meados dos anos oitenta, depois do Congresso Internacional de Saúde e Direitos Reprodutivos, ocorrido em Amsterdã, no ano de 1984. O conceito, a princípio, estava presente nas ideias fundadoras do feminismo contemporâneo que eram o direito ao próprio corpo, baseado nos princípios de autonomia e de liberdade, expressos na máxima "nosso corpo nos pertence" (SCAVONE, 2000, p.141). Os direitos reprodutivos tiveram o seu nascimento na luta do movimento feminista internacional, que se fundamentava no "direito à livre escolha da maternidade, ao aborto, à contracepção - e podem ser considerados, do ponto de vista dos direitos humanos, como uma ampliação dos mesmos" (SCAVONE, 2000, p.141). Entretanto, segundo Scavone (2000), sob o ponto de vista feminista, a noção de direitos reprodutivos possuía um significado político social mais abrangente, pois ela direcionava aos questionamentos das relações de gênero tanto no núcleo da instituição familiar como na orientação das políticas de planejamento familiar que vigoravam. "Não se tratava só de politizar as questões privadas e trazê-las para o debate público, mas, sobretudo, mediante essa luta, alcançar a equidade de gênero" (SCAVONE, 2000, p.141-142.).

A democratização do sistema político no Brasil inicia a chamada "segunda década dos direitos reprodutivos", conforme a denominação de Maria Betânia Ávila "na qual a mobilização feminista já utiliza a noção de direitos reprodutivos." (SCAVONE, 2000, p.2). Assim, o movimento feminista brasileiro nesse período passa a utilizar a noção de direitos 
direcionando-se, assim, para as questões dos direitos reprodutivos, priorizando a construção de uma política social neste campo. Nota-se que "a ligação entre saúde e direitos reprodutivos é tão estreita e direta que os limites muitas vezes foram confundidos, fazendo com que um campo fosse restringido ao outro" (REDE FEMINISTA DE SAÚDE, 2001, p.6).

O relacionamento com questão reprodutiva possibilita exigências das políticas públicas e um avanço em outras direções e campos. Dessa maneira, vários elementos vão aparecer nas reivindicações e reflexões relacionadas à saúde da mulher, tais como questionar o saber e o poder médico; a "emergência do discurso das mulheres sobre suas experiências corporais: uma crítica contundente à situação atual dos serviços de saúde; além do empenho em exigir do Estado uma maior eficácia no que se refere ao funcionamento do sistema de saúde" (REDE FEMINISTA DE SAÚDE, 2001, p.6).

No contexto do início dos anos oitenta, as lutas das mulheres elegem a saúde como tema nuclear de sua ação, com isso a saúde torna-se a peça fundamental para uma construção ou reconstrução da identidade feminina e luta pela equidade. O período anterior à década de noventa é marcado pela criação dos Conselhos Estaduais de Direitos das Mulheres, em 1985, como também do Conselho Nacional dos Direitos das Mulheres (CNDM), além de ser o período da Constituinte no qual as mulheres se organizaram em torno do desafio de influenciar a nova Constituição no avanço das definições do papel da mulher na sociedade (GRAÇA, MALAGUTI, VIEIRA, 2010).

Vale destacar, que a Constituição de 1988 se expressa em um marco na conquista dos direitos das mulheres ao considerar que tanto os homens quanto as mulheres são iguais em direitos e obrigações, como demonstra o quinto artigo da Carta Magna. Este instrumento torna-se um ganho fundamental da igualdade de direitos e de deveres entre homens e mulheres, o que até aquele momento era inexistente no ordenamento jurídico brasileiro. Essa nova Constituição, denominada de Constituição Cidadã, possibilitou um 
É interessante ressaltar, como afirmam as autoras Graça; Malaguti; Vieira (2010) que nos anos oitenta não se fazia o uso do conceito de gênero e sim apenas de categoria “políticas para as mulheres". Estas políticas foram compreendidas no reconhecimento da desigualdade e da discriminação, que eram fundamentadas na busca de retribuir às necessidades das mulheres numa perspectiva de direitos de cidadania. Foi apenas na década de noventa, início dos anos 2000, que houve uma mudança de foco nos programas específicos para as mulheres, em um enfoque de gênero, com a incorporação de um modelo que visava à diversidade, além das demais formas de desigualdade, principalmente a desigualdade de gênero.

Percebe-se que a construção de um Brasil favorável à equiparação de gênero tem sido uma das muitas batalhas que os movimentos de mulheres e feministas têm levado nos últimos anos. Mesmo assim, os movimentos feministas continuam tentado convencer os governantes e gestores públicos que é necessária a incorporação de uma visão que considere as desigualdades existentes entre homens e mulheres, porém não tem sido tarefa fácil. "Mais difícil ainda é levá-los a concluir que uma visão de gênero nas políticas públicas facilita a superação de entraves ao desenvolvimento econômico e social e a busca da justiça social.” (GRAÇA; MALAGUTI;VIEIRA, 2010).

Apesar dos direitos de autonomia reprodutiva, por meio da legalização do aborto no Brasil, serem uma luta antiga, e ocorrerem desde a década de 70, se mostram ainda como um desafio a ser vencido pelo movimento feminista. Outras conquistas foram alcançadas nos diferentes âmbitos sociais, como indica o documento denominado "Os direitos das mulheres na legislação brasileira pós-constituinte" do Centro Feminista de Estudos e Assessoria (CFEMEA). Essas “vitórias" dos direitos das mulheres abrangem avanços nos direitos sociais, na legislação, em áreas como a dos direitos humanos, dos direitos civis, violência, saúde, educação, trabalho, previdência social, assistência social, habitação e desenvolvimento, ciência e tecnologia e meio ambiente, política e poder, controle social e orçamento público. Um exemplo dessas conquistas é a implantação de 

executadas a fim de construir, ampliar e modernizar as creches com o apoio do Ministério da Previdência e Assistência Social.

Outras lutas foram travadas por direitos das mulheres, como por exemplo, em relação à violência, com a finalidade de acabar com a injusta argumentação de defesa de crimes sexuais serem cometidos por motivo de relevante valor social ou moral, ou sob o domínio de violenta emoção como se encontrava no Código Penal Brasileiro por meio do (Decreto-Lei 2.848/40), mudado em 2009, não sendo mais visto como forma de legitima defesa da honra. Os movimentos feministas combatem a premissa de que "o valor moral e a violenta emoção ainda hoje são usados como argumentos para a defesa de assassinos de mulheres que são acusadas de traírem seus maridos ou companheiros." Uma causa, hoje ganha, em que o movimento se concentrava, era a respeito do crime de estupro. $\mathrm{O}$ movimento de mulheres e feministas lutava para que o estupro fosse entendido como "qualquer relação sexual forçada (genital, anal ou oral), envolvendo mulheres e homens como vítimas", sendo aprovada tal mudança em 2009 - lei nº. 12.015 (CENTRO FEMINISTA DE ESTUDOS E ASSESSORIA, 2006, p.19). Além do reconhecimento do fenômeno da violência familiar e doméstica, que já vinha sendo sistematicamente denunciado pela luta de mulheres desde as décadas de setenta e oitenta, hoje um grande avanço se mostra com a aprovação, em 2006, da lei Maria da Penha denominação popular da Lei número 11.34.

Outras conquistas compartilhadas pelo movimento feminista estão na área da saúde, no fato dela ser considerada como um direito social, como se mostra na Constituição Federal de 1988. Fazendo com que a saúde seja considerada um direito de todos e um dever do Estado em garantir, mediante as políticas sociais e econômicas, a redução do risco de doença e de outros agravos e também ao acesso universal e igualitário às ações e serviços para sua promoção, proteção e recuperação como está no artigo 196 da Carta Magna. Havendo assim, outro ganho posterior, a legislação instituindo o Sistema Único de Saúde - SUS (8.080/1990). 
No campo da saúde reprodutiva, a Constituição realizou grande avanço "ao prever o planejamento familiar como livre decisão do casal, cabendo ao Estado propiciar recursos educacionais e científicos para o seu exercício, vedando qualquer forma coercitiva por parte de instituições oficiais ou privadas", conforme o artigo 226, parágrafo $7^{\circ}$. Também foi inserido no Código Civil (Lei 10.406/2002, art. 1.565, parágrafo 20), artigo com o mesmo sentido. Apenas oito anos depois de promulgada a Constituição, o planejamento familiar foi regulamentado em lei (Lei 9.263/1996). Tal lei define que o planejamento familiar visa um "conjunto de ações de regulação da fecundidade, garantida pelos direitos de constituição, com a possibilidade de limitação ou aumento da prole pela mulher, pelo homem ou pelo casal, cabe a eles a decisão." (CENTRO FEMINISTA DE ESTUDOS E ASSESSORIA, 2006, p.21).

As lutas relacionadas às questões reprodutivas desdobram outros assuntos interligados a ela, como por exemplo, a esterilização voluntária de mulheres e de homens, reprodução humana assistida, normas regulamentadoras das clínicas de reprodução humana, obrigatoriedade dos planos de saúde de cobrirem o atendimento em caso do planejamento familiar, fertilização de óvulos humanos e outros assuntos que geram atualmente proposições legislativas em tramitação no Congresso Nacional. Buscam também alterar a forma como é compreendido o planejamento familiar a fim de restringir direitos até mesmo já assegurados. Observa-se que muitas dessas resistências expressas em projetos de lei têm uma grande influência de religiões, enfim de uma bancada parlamentar religiosa, de unidade entre católicos e evangélicos.

Quanto ao aborto, a sua relação com a legislação é mais polêmica, tal como mencionado na introdução. E a sua demanda pela descriminalização do aborto é antiga no movimento feminista motivando, assim, a criação de ações em eventos, como por exemplo, a Frente Feminista de Direitos Sexuais e Reprodutivos, em 1991, as Jornadas pelo Direito ao Aborto Legal e Seguro, em 2004, que envolveu grupos em toda a América Latina que tinha como slogan adotado "A mulher decide, a sociedade respeita, e o Estado garante" e outros eventos mais recentes como, por exemplo, o promovido pela ONG feminista Católicas pelo Direito de Decidir, com apoio do grupo Fundo Social Elas, que 
Os movimentos de mulheres têm como centralidade a defesa dos direitos reprodutivos da mulher, além da descriminalização e da legalização do aborto partindo do fundamento de laicidade do Estado brasileiro, como também do direito à saúde e soberania das mulheres em relação às suas próprias vidas.

Apesar de existirem algumas ações por parte do Ministério da Saúde por meio de normas técnicas como a "Norma Técnica de Atenção aos Agravos da Violência Sexual contra Mulheres e Adolescentes", de 2002, que foi implantada quando José Serra era ministro da Saúde, a fim de garantir o aborto previsto por lei, orientando os profissionais da Rede Pública de Saúde sobre como proceder com um atendimento mais humanizado de mulheres em situação de violência sexual, incluindo a pílula do dia seguinte e a possibilidade de interrupção da gravidez ou aborto nos casos de gravidez resultante de estupros. No entanto, apesar da norma, nota-se que ainda há um caminho grande a ser percorrido para uma atenção sem julgamentos e resistência profissional diante de mulheres que desejam abortar.

O feminismo tem centrado sua luta também na garantia da aplicação da lei que assegura o aborto legal nos dois casos previstos pelos incisos do artigo 128 do Código Penal Brasileiro: o risco de vida para a gestante ou quando o feto foi gerado em decorrência de um estupro, como também busca ampliá-la para outros casos. Por exemplo, em caso de acefalia e anencefalia fetal, além de traçar uma batalha maior pela descriminalização e legalização da prática. A luta das mulheres para considerar o aborto como um exercício de autonomia reprodutiva tem apoio também de grupos ligados a religiões, como o grupo já mencionado "Católicas pelo Direito de Decidir (CDD). Este “constitui uma oposição importante no seio da própria Igreja Católica, a qual tem sido tradicionalmente uma força importante contra a legalização do aborto no país." (REDE FEMINISTA DE SAÚDE, 2001). No site do grupo, elas, "Católicas pelo Direito de Decidir" se definem da seguinte forma:

Católicas pelo Direito de Decidir é uma entidade feminista, de caráter inter-religioso, que busca justiça social e mudança de padrões culturais e 
religiosos vigentes em nossa sociedade, respeitando a diversidade como necessária à realização da liberdade e da justiça. Constituiu-se no Brasil em 1993, formalizando-se juridicamente em 1994, e atua em articulação com uma rede latino-americana (Católicas por El Derecho a Decidir), com Catholics for Free Choice, dos Estados Unidos, e com companheiras na Espanha. $\mathrm{CDD} / \mathrm{Br}$ promove os direitos das mulheres (especialmente os sexuais e os reprodutivos) e luta pela igualdade nas relações de gênero e pela cidadania das mulheres, tanto na sociedade quanto no interior da Igreja Católica e de outras igrejas e religiões, além de divulgar o pensamento religioso progressista em favor da autonomia das mulheres, reconhecendo sua autoridade moral e sua capacidade ética de tomar decisões sobre todos os campos de suas vidas. (CATÓLICAS PELO DIREITO DE DECIDIR, 2010,)

Outros segmentos e organizações apóiam a luta das mulheres pela autonomia reprodutiva, a exemplo de eventos como o ocorrido no ano de 2008 , em São Paulo. O seminário "Estratégias Latino-Americanas pela legalização do aborto e autonomia reprodutiva das mulheres" foi organizado e promovido pelo CFEMEA juntamente com outras organizações e redes, como Instituto Feminista para a Democracia - SOS Corpo, Ações Afirmativas em Direitos e Saúde - AADS - IPAS Brasil, Associação Médica Brasileira AMB e outras. Porém, mesmo com essa luta promovida e apoiada por organizações e diferentes entidades, a questão da autonomia feminina é minada em pleno século XXI. (CENTRO FEMINISTA DE ESTUDO E ASSESSORIA, 2008).

(...) houve uma reunião do Conselho Nacional de Saúde, para a qual o atual presidente da Comissão de Seguridade Social e Família, deputado Jofran Frejat (PR/DF), foi convidado. A pauta principal era discutir com o deputado sobre alguns projetos de lei, que tramitam naquela comissão, propondo retroceder direitos sexuais e reprodutivos já conquistados pelas mulheres. No entanto, o deputado não compareceu. (CENTRO FEMINISTA DE ESTUDO E ASSESSORIA, 2010)

Muitos desses grupos participam de movimentos ou eventos internacionais para que o aborto seja descriminalizado, pois além dos direitos sexuais e reprodutivos pressuporem a liberdade individual, são também uma questão de justiça social, saúde pública, de igualdade e equidade de gênero. Eventos Internacionais como, por exemplo, a IV Conferência Mundial sobre a Mulher realizada em Pequim em 1995. Sobre os direitos reprodutivos o documento assinala: 
Na maior parte dos países, a falta de atenção aos direitos reprodutivos da mulher limita gravemente suas oportunidades de educação e o pleno exercício de seus diretos econômicos e políticos. A capacitação das mulheres para controlar sua própria fertilidade constitui uma base fundamental para o gozo de outros direitos. A responsabilidade compartilhada pela mulher e pelo homem, no tocante às questões relativas ao comportamento sexual e reprodutivo, também é indispensável para o melhoramento da saúde da mulher. (DECLARAÇÃO E PLATAFORMA DE AÇÃO DA IV CONFERÊNCIA MUNDIAL SOBRE A MULHER, 1995, p.179)

Em relação às práticas abortivas, a Conferência Mundial sobre a Mulher afirma que “o aborto inseguro põe em risco a vida de um grande número de mulheres e representa um grave problema de saúde pública" devido às más condições em que são feitos (DECLARAÇÃO E PLATAFORMA DE AÇÃO DA IV CONFERÊNCIA MUNDIAL SOBRE A MULHER, 1995, p.179). Tal documento também frisa que o aborto não deve ser promovido como método contraceptivo no planejamento familiar, porém os governos devem dar assistência na área da saúde para mulheres que desejam abortar quando o caso é garantido por lei. Os compromissos internacionais, como os firmados na Conferência de Pequim, após serem reiterados pelo Brasil, dão origem a novos programas governamentais a fim de conseguir garantir aquilo que foi proposto por meio da assinatura de compromisso do Brasil. O III Programa Nacional de Direitos Humanos de 2009 explicita isso em seu texto, na parte denominada "Propostas de Ações Governamentais - Propostas Gerais", que se subdivide em várias garantias de direito, como a "Garantia do Direito à Saúde, à Previdência e à Assistência Social":

Divulgar o conceito de direitos reprodutivos, com base nas plataformas do Cairo e de Pequim, desenvolvendo campanhas de pré-natal e parto humanizado, bem como implementando comitês de prevenção da mortalidade materna e da gravidez na adolescência. (BRASIL, 2009, p.21)

Já na parte do documento chamada de "Objetivo estratégico IV: Ampliação do acesso universal a sistema de saúde de qualidade", a sexta ação das "Ações programáticas" afirma:

f) Criar campanhas e material técnico, instrucional e educativo sobre planejamento reprodutivo que respeite os direitos sexuais e direitos reprodutivos, contemplando a elaboração de materiais específicos para a população jovem e adolescente e para pessoas com deficiência. (BRASIL, 2009, p.61). 
Observa-se que no fim de cada ação programática aparecem os responsáveis por ela, no caso da ação de letra “f” são: Ministério da Saúde; Secretaria Especial de Políticas para as Mulheres da Presidência da República e Secretaria Especial dos Direitos Humanos da Presidência da República.

O I Plano Nacional de Políticas para as Mulheres, também lançado em 2004, contempla a questão dos direitos reprodutivos. Na apresentação, o documento assinala que:

O Plano está estruturado em torno de quatro áreas estratégicas de atuação: autonomia, igualdade no mundo do trabalho e cidadania; educação inclusiva e não sexista; saúde das mulheres, direitos sexuais e direitos reprodutivos; e, enfrentamento à violência contra as mulheres. Em relação a estas áreas estão contempladas as políticas e ações que devem ser desenvolvidas ou aprofundadas para que mudanças qualitativas e quantitativas se efetivem na vida das mulheres brasileiras. Outro desafio que se apresenta diz respeito à gestão e monitoramento do Plano que tem como fundamento a transversalidade de gênero. (BRASIL, 2004, p.13)

No terceiro capítulo, intitulado de "Saúde das mulheres, direitos sexuais e direitos reprodutivos", que contempla os objetivos, metas, prioridades e plano de ação, a questão dos direitos reprodutivos também aparece:

I. Promover a melhoria da saúde das mulheres brasileiras, mediante a garantia de direitos legalmente constituídos e ampliação do acesso aos meios e serviços de promoção, prevenção, assistência e recuperação da saúde, em todo território brasileiro. II. Garantir os direitos sexuais e direitos reprodutivos das mulheres. (BRASIL, 2004, p.61)

Verifica-se que no II Plano Nacional de Políticas para as Mulheres, lançado em 2008, há uma maior articulação sobre os direitos reprodutivos como se pode observar na citação abaixo:

A avaliação do I PNPM apontou como principais avanços na institucionalização da Política Nacional para as Mulheres e na sua implementação: a maior inserção da temática de gênero, raça/etnia no processo de elaboração do orçamento e planejamento do governo; a criação de organismos governamentais estaduais e municipais para coordenação e gerenciamento das políticas para as mulheres; e os avanços na incorporação da transversalidade de gênero nas políticas públicas. Mereceram destaque, ainda, a promulgação da Lei 11.340/2006 (Lei Maria da Penha), a criação da Comissão Tripartite para a Revisão da Legislação Punitiva contra o Aborto, o aumento de crédito das mulheres 
rurais e a política nacional de direitos sexuais e direitos reprodutivos, entre outros. (BRASIL, 2008, p.24)

O II Plano Nacional de Políticas para as Mulheres parece indicar que o aborto é um problema de saúde pública apresentando que a sua prática clandestina é uma das principais causas de morte de mulheres no Brasil e assim propondo uma revisão legislativa da questão para garantir o aborto legal. São objetivos específicos do II Plano Nacional de Políticas para Mulheres: "garantir os direitos sexuais e direitos reprodutivos das mulheres em todas as fases do seu ciclo de vida e nos diversos grupos populacionais, sem discriminação de qualquer espécie” como também são prioridades do Estado “propor alterações de legislação com a finalidade de ampliar a garantia do direito à saúde, contemplando os direitos sexuais e direitos reprodutivos das mulheres e o fortalecimento do Sistema Único de Saúde” (BRASIL, 2008, p.77-78). A luta pelos direitos sexuais e reprodutivos das mulheres tem como parcerias: Secretaria de Políticas de Promoção da Igualdade Racial - SEPPIR, movimentos feminista e de mulheres, Ministérios, Advocacia Geral da União - AGU, sociedades científicas, entidades de classe e articulação com o poder legislativo na elaboração/revisão de leis e/ou projetos de lei com o movimento social.

Algumas medidas foram tomadas em relação aos direitos sexuais e reprodutivos: o então presidente Luiz Inácio Lula da Silva, em 2005, lançou a "Política Nacional de Planejamento Familiar, uma parceria do Ministério da Saúde com a Secretaria Especial de Políticas para as Mulheres, que fortaleceu a Política Nacional de Direitos Sexuais e Direitos Reprodutivos" (BRASIL, 2008, p.76). Essa política incluiu a prática da vasectomia na Política Nacional de Cirurgias Eletivas, a distribuição de anticoncepcionais em farmácias e drogarias credenciadas no Programa Farmácia Populares com preços mais baratos, além do credenciamento de novos serviços nos hospitais públicos para a realização de laqueaduras, a fim de garantir os direitos de homens e mulheres em relação à saúde sexual e à saúde reprodutiva e, principalmente, o planejamento familiar. ${ }^{6}$

\footnotetext{
${ }^{6}$ Ver as diretrizes do governo no documento do Ministério da Saúde: BRASIL. Direitos Sexuais e Direitos Reprodutivos: uma prioridade do governo/Ministério da Saúde, Secretaria de Atenção à Saúde, Departamento de Ações Programáticas Estratégicas - Brasília: Ministério da Saúde, 2005.
} 
As cidades e os estados brasileiros também promoveram políticas relativas aos direitos reprodutivos, como as "Políticas Públicas e Igualdade de Gênero", promovidas por Marta Suplicy, na época prefeita de São Paulo no período de 2001 a 2005, traz também a luta pela descriminalização da prática abortiva além de garantir "o exercício dos direitos reprodutivos e sexuais, com destaque para a legalização do aborto e o acesso universal a serviços de saúde que garantam a sua realização, contemplando as mulheres em suas diferentes fases", além de consolidar a liberdade de escolha individual (GODINHO, 2004, p.154).

Diante do exposto, é possível avaliar que os instrumentos citados acima simbolizam grande parte da luta do feminismo, que ainda hoje possui um longo caminho a seguir, pois há uma necessidade de garantir alguns direitos já assegurados por lei, como também de expandir legalmente outros, como no caso dos direitos reprodutivos e da legalização do aborto aqui discutidos. Contudo, compreender o aborto como uma forma de autonomia reprodutiva é um campo minado ainda no século XXI no Brasil. Averigua-se que essas questões possuem um estreito vínculo com a legislação brasileira e para compreendê-lo melhor, o próximo tópico irá abranger questões relacionadas à esfera legal. Foi verificado também nesse texto que o movimento feminista utilizou-se do campo da saúde, como indica a Rede Feminista de Saúde (2001), para promover as reivindicações de seus direitos e, apesar da consolidação de algumas políticas públicas, essas se mostram ainda de forma parcial em suas efetivações, principalmente pragmáticas, como algumas relacionadas à saúde, o que será contemplado nos próximos tópicos.

Por fim, afirma Scavone (2008, p.678) que ainda "paira no ar a dúvida de que lutas parciais (...) impossibilitem ou retardem uma luta mais radical que proponha frontalmente uma ampla legalização do aborto, o que de qualquer maneira não invalida a importância do que já está sendo feito", já que essas questões tangem aquilo que cabe ao Estado fazer como também envolvem os direitos humanos e o respeito da liberdade fundamental para os direitos civis, políticos, econômicos, sociais e culturais, não somente do gênero feminino, como de todos, por esses serem essenciais para o desenvolvimento das sociedades em todo o mundo. 
em torno da manutenção da criminalização ou pela descriminalização parcial ou total da prática abortiva. Esse conflito se encontra na esfera legal por meio da apresentação de diversos projetos de lei que visam ora a descriminalização do aborto, como por exemplo, os projetos de lei 1135/91 e 176/1995; ora alguns outros projetos contrários, como os projetos de lei 4703/1998 e 5364/2005. Vale sublinhar que não há uma pretensão nesse tópico de mapear, mencionar ou ainda descrever todos os projetos de leis existentes ou que existiram em relação à prática abortiva, mas sim perceber por meio desses exemplos a luta travada que existe em torno da descriminalização e da criminalização do aborto na esfera legal no Brasil.

A sociedade brasileira conviveu com a lei proclamada em 1940 - o Código Penal que criminaliza o aborto sem maiores contestações até que pautas sobre o tema apareceram no movimento feminista da década de setenta, como vimos no tópico anterior.

Porém, de acordo com Diniz (2001, p.1), “desde a promulgação do Código Penal Brasileiro em 1940, o tema do aborto vem sendo pauta legislativa constante no país." Segundo a autora, o primeiro projeto de lei sobre o aborto foi proposto em 1949, e tratava-se de uma proposta pela criminalização do aborto em sua totalidade, em todos os casos. Esse PL de 1949 teve como autor o deputado monsenhor Arruda Câmara que, com a aprovação de seu projeto de lei, pretendia suprimir do Código Penal os dois permissivos legais referentes à prática do aborto, ou seja, nas situações de risco de vida da gestante e de gravidez que resulta de estupro. Para Rocha (2008, p.1), a apresentação desse projeto com a abertura do Congresso logo depois Estado Novo, "é realizada por um integrante da Igreja Católica, um dos principais atores políticos nessa discussão - é o marco inicial de um debate que vem se prolongando até os dias de hoje no Parlamento."

A primeira iniciativa de reforma legal da lei, visando a legalização do aborto aconteceu em 1983, quando um projeto de lei foi apresentado à Comissão de Constituição 
e Justiça da Câmara dos Deputados, mas que foi rejeitado. (FREITAS, 2011, p.10). ${ }^{7}$ Em 1985, no Rio de Janeiro, a Assembléia Legislativa aprovou o projeto de lei que obrigava o serviço público de saúde a oferecer o procedimento para o aborto nos dois casos previstos pelo Código Penal. Observa-se que o então governador do estado, num primeiro momento, sancionou e depois vetou o mesmo projeto. Mas a proposta de assegurar na rede pública de saúde o acesso ao aborto nos casos de risco de vida e estupro foi retomada pela administração municipal de São Paulo com a criação do primeiro serviço público para o atendimento dos casos de aborto previstos pela lei penal, no Hospital do Jabaquara, no ano de 1990. (FREITAS, 2011).

Em 1989, o deputado José Genoíno apresentou um projeto de lei 3.465/1989, (anexado ao PL 2.438/89) ${ }^{8}$ que "propunha a opção livre pela interrupção da gravidez por meio do questionamento dos princípios religiosos que regiam as discussões sobre o aborto. Ele afirmou que o aborto era um direito da mulher de dispor de seu próprio corpo" (AMARAL, 2008, p.2). Esse PL afirmava que o aborto inseguro era um grave problema de saúde e não podia ser visto como um problema moral ou religioso.

No ano de 2001, a responsável pela relatoria do conjunto de projetos que propunham alteração do Código Penal, a deputada Jandira Feghali (PCdoB/ RJ), “apresentou um substitutivo ao PL 1135/91, com parecer favorável à aprovação de todas as propostas liberalizantes e rejeição dos projetos restritivos" (FREITAS, 2011, p.11).

\footnotetext{
7 "O Projeto de Lei n ${ }^{\circ}$ 590-A, de 1983, da deputada Cristina Tavares, que não propôs a descriminalização do auto-abortamento e do aborto consentido, mas simplesmente buscou ampliar os espectros das indicações permissivas para os casos de aborto, quanto aos aspectos médicos, éticos e sociais; bem como o Projeto de Lei $n^{\circ} 1651$, de 1983, do deputado Denisar Arneiro, mais ousado e que chega a propor a não punição "quando a gestante manifestar perante o juiz o desejo de não prosseguir na gravidez", dentre outras considerações, em seu parecer afirmou: "Se há o perigo do nascimento de crianças portadoras de graves males, a solução do problema não estará na transformação do país num imenso abortário. As medidas para prevenir esse risco apavorante devem ser tomadas no sentido da própria vida, e nunca na direção da morte". E, com o voto em separado, o deputado Valmor Giavarina ponderou: "Assim, em nome do Direito da Mulher pretende-se proclamar o 'Direito de Matar', desde que se o faça através de médico especializado transformado em carrasco de fetos." (PIMENTEL, 1985, p. 19).

${ }^{8}$ Projeto de Lei $n^{\circ} 2.438 / 89$ de autoria do Deputado Inocêncio Oliveira pretendia autorização de atividades de práticas e meios anticoncepcionais e de outras providências a fim de evitar a concepção de todos os casais ou mulheres maiores de idade que desejassem no Brasil. (CONSELHO FEDERAL DE MEDICINA, 2010).
} 
O substitutivo de Jandira Feghali retira do Código Penal os artigos 124 e 126, que estabelecem punição para o aborto provocado pela gestante ou com seu consentimento; o artigo 127, que trata da forma qualificada de aborto (casos em que a gestante sofre lesão corporal grave ou morre em decorrência dessas lesões); e o artigo 128, que se refere aos casos em que o aborto não é punido (gravidez resultante de estupro ou em que a mulher corra risco de vida). Com isso, o texto descrimina a prática interrupção da gravidez. O projeto original foi apresentado pelos exdeputados Sandra Starling e Eduardo Jorge. (CEFEMEA, 2005 a, s.p)

Entre os projetos de leis pela descriminalização, aqueles que se mostram também de datas antigas são os PL 1135/1991 e PL 20/1991, ambos de autoria de Eduardo Jorge (PTSP). Este último propõe a obrigatoriedade de que os abortos (nos casos de estupro e risco de morte para a mãe) sejam realizados pelo SUS. Todavia, o PL 1135/1991 de autoria de Eduardo Jorge (PT-SP) como também de Sandra Starling (MG-SP) que está apensado no PL 176/1995 de José Genuíno (PT-SP), que permite a interrupção da gravidez até 90 dias e obriga a rede hospitalar pública a realizar o procedimento, está em tramitação no congresso. São dois projetos que "propõem avanços na legislação na medida em que buscam uma resposta mais adequada a um grave problema de saúde pública como é a prática do aborto quando realizada em condições inseguras e clandestinas" (CEFEMEA, $2008 \mathrm{a}, \mathrm{s} / \mathrm{p})$.

O texto que compõem o projeto de lei 1135/1991 traz a seguinte justificativa:

O presente projeto de lei tem por objetivo atualizar o Código Penal, adaptando-o aos novos valores e necessidades do mundo atual, particularmente no sentido do reconhecimento dos direitos da mulher enquanto pessoa humana. $\mathrm{O}$ artigo que se suprime penaliza duramente a gestante que provoca aborto ou consente que outro o realize. Esta é uma disposição legal ultrapassada e desumana. O Código penal data de 1940 e nestes últimos cinquenta anos, nossa sociedade passou por profundas transformações, notadamente no que se refere ao papel da mulher. Sua participação tem-se caracterizado, entre outros aspectos, pela crescente sobrecarga de trabalho, associando suas funções domesticas às do trabalho assalariado, quase em condições desfavoráveis em relação aos demais trabalhadores. São essas mulheres, em sua maioria de classe social baixa, obrigadas a submeter-se à pratica do aborto, que vão compor a triste estatística de cerca de 4.000 .000 (quatro milhões) de casos em todo Brasil. Essa prática realizada sem as condições técnicas necessárias tem provocado um alto índicie de mortalidade, contribuindo fortemente para levar o País a uma taxa de 
mortalidade materna várias vezes superior às dos países da Europa. Portanto, a lei não pode pretender punir baseando-se apenas na compreensão isolada e individual do ato e desconsiderando toda a realidade social a que está submetida a mulher brasileira. Ademais, é absolutamente desnecessário e desumano querer aplicar penalidade a uma pessoa que já foi forçada a submeter-se a tamanha agressão. A gestante, quando provoca o aborto em si mesma ou permite que outro o faça, está tomando uma providência extrema que a violenta física, mental e, com frequência, moralmente. Pelo exposto e no sentido de reparar mais uma entre as injustiças contra a mulher, conclamamos os ilustres pares a aprovar este projeto de lei. (JORGE; STARLING, 1991, s.p)

O projeto de lei descrito acima, da mesma maneira que outros comumente identificados como pró-aborto (ou porque lutam para descriminalização, ou pelo reconhecimento de que se trate de problemas de saúde pública, ou porque ainda querem fazer cumprir os preceitos legais, como no caso do atendimento pelo SUS), possui uma grande resistência no Congresso, principalmente da bancada religiosa, presente nele. Essa bancada contempla uma ala evangélica forte e organizada que se opõem ao projeto de descriminalização do aborto, entretanto não são apenas de cunho religiosos, mas também partidos de matizes mais conservadores.

Segundo o projeto, "o tema da descriminalização e legalização do aborto é de fato polêmico e complexo e por isso merece uma atenção especial da sociedade e do Congresso, que não vem conseguindo responder de forma adequada" (CEFEMEA 2008 a, s.p). A tramitação do projeto de lei 1135/1991 passa por várias ações ${ }^{9}$ sendo que a última data de 31 de janeiro de 2011 e se encontra arquivada nos termos do Artigo 105 do Regimento Interno da Câmara dos Deputados. Publicação no DCD do dia 01/02/2011 Suplemento ao $\mathrm{n}^{\circ}$ 14, Mesa Diretora da Câmara dos Deputados (MESA).

Os projetos que visam a descriminalização do aborto geram opiniões divergentes como a do Conselho Nacional dos Bispos do Brasil - CNBB que afirma:

Há projetos de lei no Congresso Nacional para legalizar a prática do aborto! Há mesmo quem pretenda que isso é um direito humano. Tirar a vida de seres humanos inocentes e indefesos seria um direito humano?! Para camuflar a realidade, fala-se em "despenalização"ou "descriminalização" do aborto, "interrupção da gravidez" ou "parto

\footnotetext{
9 Ver a tabela de datas de ações, pareceres no site da câmara dos deputados no link: <http://www.camara.gov.br/proposicoesWeb/fichadetramitacao?idProposicao=16299>
} 
antecipado"... O objetivo é sempre o mesmo: Legalizar a supressão da vida de seres humanos inocentes e indefesos. (...) Há também quem argumente que a mulher teria o direito de decidir sobre seu próprio corpo; tratando-se da gravidez, há nisso um equívoco primário, pois o feto ou bebê, que ela traz no útero, não é parte do seu corpo, mas outro corpo, diverso do dela; melhor dito, é um outro ser humano, diverso dela. A natureza da mulher recebeu de Deus a bela e gratificante missão de conceber e acolher a vida humana, de fazê-la vir ao mundo, de amparar e proteger esta vida frágil e linda. Evidentemente, desaprovando o aborto, não queremos a todo custo o castigo das mulheres que, por alguma razão, o praticam. A proibição legal da prática do aborto não visa o castigo, mas a proteção do direito à vida. Porém, como proteger a vida nascente e assegurar o primeiro de todos os direitos humanos, se 0 aborto fosse legalizado? O Estado não pode ser relapso em fazer cumprir a lei existente, sobretudo contra clínicas clandestinas (nem tão clandestinas), que exploram o mercado do aborto. (SCHERER, 2010, s.p)

Em contrapartida à luta pela descriminalização do aborto, se encontra a luta pela sua criminalização. O projeto de lei, como por exemplo, PL 4703/1998, de autoria de Francisco Silva - PPB/RJ, de teor contrário à descriminalização da prática abortiva, tem como pretensão "que o aborto praticado tanto pela gestante como por terceiros seja considerado um crime hediondo" (SENADO FEDERAL, 2004, 314). Já a proposição: PL 7235/2002 de autoria de Severino Cavalcanti - PPB /PE, busca a alteração do Código Penal, "revogando dispositivo que autoriza a realização do aborto necessário no caso de não haver outro meio de salvar a vida da gestante e no caso de gravidez resultante de estupro." (SENADO FEDERAL, 2004, 472). O projeto de lei 5364/2005 do deputado Luiz Bassuma - PT/BA “deseja criminalizar o aborto cuja gravidez foi resultante de estupro.” (GONÇALVES, 2008, p.79). Segundo o Centro Feminista de Estudos e Assessoria CFEMEA (2007 b) esses projetos de leis e outros que almejam a criminalização do aborto até em casos permitidos por lei, ameaçam os direitos conquistados pelas mulheres e revelam um descaso dos parlamentares com a saúde delas, pois:

Negam o direito ao aborto seguro às vítimas de estupro e às mulheres em risco de morte - PDC 42/2007, do deputado Henrique Afonso (PT-AC): susta a norma técnica de 1998 que instrui aos hospitais do Sistema Único de Saúde (SUS) a praticarem aborto seguro em caso de gestações decorrentes de estupro até o quinto mês; e constrange as mulheres na hora de exercer seus direitos - PL 831/2007, do deputado Odair Cunha (PT-MG): determina a criação, nos hospitais que prestam atendimento em aborto legal, de programas para orientar mulheres sobre os efeitos e métodos utilizados no procedimento, de forma a tentar dissuadi-las da 
Vale lembrar a existência de projetos de leis que são considerados neutros, pois não se posicionam nem a favor nem contra a descriminalização e criminalização da prática.. Esses projetos de lei propõem apenas o plebiscito para que a sociedade decida sobre a questão. Há no Congresso Nacional, O PDC 1757/2005 de autoria do deputado Osmânio Pereira (PTB-MG) documento que convoca um plebiscito para que a população decida acerca da legalização do aborto até a $12^{\mathrm{a}}$ semana de gravidez. (CFEMEA, 2005 b). E outro que tramita no Senado, o Projeto de Decreto Legislativo - PDS 1494/2004 do autor Gerson Camata (PMDB-ES) que determina a realização de plebiscito sobre o aborto dentre outros temas polêmicos (CONGESSO EM FOCO, 2010).

Em relação ao projeto sobre o aborto denominado neutro o CEFEMEA assinala:

Em dezembro, O PDS 1494/2004 chegou a ser incluído na pauta da Comissão de Direitos Humanos e Legislação Participativa do Senado, mas não foi votado. O parecer do senador Paulo Duque (PMDB - RJ) ao projeto exclui o aborto do rol de temas que devem passar por plebiscito. Essa retirada representa um ganho para as mulheres. Pela interpretação de Sonia Corrêa, pesquisadora da associação brasileira interdisciplinar de AIDS, a legalização do aborto não é uma questão que possa ser resolvida pela imposição de maiorias sobre minorias. Isso porque implica decisão ética privada, que não deve estar sujeita à interferência do Estado. Assim, a maior parte dos países em que o aborto foi legalizado se deu por via legislativa ou por decisão de cortes constitucionais. (CEFEMEA, 2007 a, p.2).

Observa-se que existem divergências sobre o aborto tanto entre as autorias de projetos de leis como também em relação à maneira como esses são interpretados pelos setores da sociedade, como os grupos feministas e religiosos. É interessante ressaltar que mesmo o aborto sendo legalizado em caso de risco a gestante e de gravidez advinda de violência sexual como o estupro, a gestante que acaba de praticá-lo não encontra somente resistência para o atendimento nos hospitais, mas também na esfera legal. Projetos de lei como PL 20/1991, demonstram essa luta pela efetivação daquilo que é garantido por lei. Segundo Scavone (2000, p.8) "esses dois permissivos legais foram 
premissa do direito à vida desde a concepção, porém esta foi arquivada no ano seguinte, em 1996.

A exemplo desses embates, entre considerar a prática do aborto um crime ou não, também está no novo Código Civil que garante o "direito a vida a todos". A Parte Geral, Livro I - Título das Pessoas Naturais - Capítulo I Da Personalidade e da Capacidade informa o seguinte: "Art. $2^{\circ}$ - A personalidade civil da pessoa começa do nascimento com vida; mas a lei põe a salvo, desde a concepção, os direitos do nascituro" (BRASIL, 2010 a, s.p).

Assim como o Art. 2 do Código Civil, também o Estatuto da Criança e do Adolescente, coloca em xeque as permissões do aborto garantidas por lei. De acordo com a lei de 8.069 de treze de julho de 1990, o então presidente, Fernando Collor de Mello sancionou o Estatuto da Criança e do Adolescente (ECA), que entre os seus 267 artigos, apresenta $07^{\circ}$, que dispõe sobre o direito a vida e garante que toda criança nascitura tem direito à vida, mediante a efetivação de políticas públicas que permitam o seu nascimento.

No Estatuto no Livro I, Parte Geral, nos Títulos II Dos Direito Fundamentais Capítulo I Do Direito à Vida e à Saúde se encontra da seguinte forma:

Art. $7^{\circ}$ - A criança e o adolescente têm direito a proteção à vida e à saúde, mediante a efetivação de políticas sociais públicas que permitam o nascimento e o desenvolvimento sadio e harmonioso, em condições dignas de existência. (BRASIL, 1990, s.p)

O que coloca em xeque os incisos que garantem o aborto por lei é o fato do próprio Estatuto da Criança e do Adolescente contradizê-lo naquilo que ele condiz sobre o direito de proteção à vida. Enfim, um (o Código Penal) permite "o não nascimento (em caso de estupro e risco de vida a gestante)" e outro (o Estatuto da Criança e do Adolescente) garante “o nascimento". A lei ao mesmo tempo põe e dispõe do direito sobre a vida. 
Ainda sobre a luta pela descriminalização do aborto no Brasil é válido sublinhar que, na Conferência Internacional sobre População e Desenvolvimento no Cairo, capital do Egito, em 1994, reconheceu-se o aborto como grave problema de saúde pública. Lá foram garantidos os direitos reprodutivos e sexuais das mulheres. Este se tornou um país signatário de acordos internacionais (CFEMEA, 2010). ${ }^{10}$

É interessante ressaltar que um ano mais tarde, em 1995, na Conferência Mundial sobre a Mulher de Pequim, "foi adotada recomendação de que os países revissem as leis que punem as mulheres que recorrem à interrupção voluntária da gravidez" (FREITAS, 2011, p. 10).

Segundo o texto da CFEMEA (2008, s.p) essa recomendação se encontra no texto da Conferência no "parágrafo 106 K da Plataforma de Ação de Beijing”, que dispõe que "os governos devem considerar revisarem as leis que contém medidas punitivas contra mulheres que realizaram abortos ilegais."

Ainda, segundo também o próprio texto da Conferência de Pequim, existe uma necessidade de revisão das leis que criminalizam a prática abortiva, pois:

O aborto inseguro põe em risco a vida de um grande número de mulheres e representa um grave problema de saúde pública, porquanto são as mulheres mais pobres e jovens as que correm os maiores riscos. A maioria dos óbitos, problemas de saúde e lesões podem ser evitados, mediante a melhoria do acesso a serviços adequados de atendimento à saúde, métodos de planejamento familiar eficazes e sem riscos e atenção obstetrícia de emergência, que reconheçam o direito de mulheres e homens à informação e ao acesso a métodos seguros, eficazes, exequíveis e aceitáveis de planejamento familiar, assim como a outros métodos lícitos que decidam adotar para o controle da fecundidade e o acesso a serviços adequados de atendimento à saúde, propícios a que a gravidez e o parto transcorram em condições de segurança e ofereçam aos casais as maiores possibilidades de ter um filho são. (DECLARAÇÃ̃ E PLATAFORMA DE AÇÃO DA IV CONFERÊNCIA MUNDIAL SOBRE A MULHER, 1995, p. 179)

\footnotetext{
${ }^{10}$ Conferência Internacional de População e Desenvolvimento (Cairo, 1994), a IV Conferência Mundial sobre a Mulher (Beijing, 1995), a Cúpula sobre Desenvolvimento Social (1995), a Sessão Especial da Assembleia Geral das Nações Unidas sobre a Conferência Internacional sobre População e Desenvolvimento (1999), a Resolução da Declaração do Milênio das Nações Unidas, adotada pela Assembleia Geral (2000) e a Sessão Especial da Assembleia Geral das Nações Unidas sobre a IV Conferência Mundial sobre a Mulher. (CFEMEA, 2010, s.p).
} 
A declaração afirma também que aqueles que são contra a descriminalização do aborto devem:

(...) reconhecer que as consequências, para a saúde, dos abortos feitos em más condições constituem um grande problema de saúde pública e, conforme acordado no parágrafo 8.25 do Programa de Ação da Conferência Internacional sobre População e Desenvolvimento, buscar remediar esse problema (...).(DECLARAÇÃO E PLATAFORMA DE AÇÃO DA IV CONFERÊNCIA MUNDIAL SOBRE A MULHER, 1995 P.182 )

Embora o Brasil tenha referendado as declarações internacionais descritas acima e reafirmado em conferências posteriores o reconhecimento de que os abortos clandestinos constituem grave problema de saúde pública, a descriminalização do aborto ainda enfrenta fortes resistências de diversos setores da sociedade brasileira (FREITAS, 2011).

Observa-se que os projetos de leis pela descriminalização parcial e total do aborto esbarram em outros projetos de leis, decisões do Supremo Tribunal de Justiça, do Novo Código Civil e do Estatuto da Criança e do Adolescente que, direta ou indiretamente, contribuem com ideias ou concepções referentes à manutenção da criminalização do aborto.

Como já mencionado, o status jurídico do aborto no Brasil definido no Código Penal de 1940 é crime, salvo em dois casos: quando a gravidez põe em risco a vida da gestante; e quando o feto é gerado por estupro. Porém, esse status atual do aborto gera embates até os dias atuais. Entre os dezenove projetos de lei que tratam do aborto e que tramitam na Câmera dos Deputados e no Senado Federal, no congresso e no senado, seis projetos são pró-aborto, onze projetos são contra o aborto e dois projetos são neutros.

Outros entraves demonstram como a luta entre a criminalização e descriminalização da prática abortiva é percebida e segue acirrada na esfera legal. Ainda pela conquista da criminalização do aborto, no dia vinte e cinco de setembro de 1992, o Brasil ratificou a Convenção Americana de Direitos Humanos, que dispõe, em seu artigo $4^{\circ}$, que o direito à vida deve ser protegido desde a concepção.

O documento da Covenção Americana de Direitos Huamanos na Parte I - Deveres dos Estados e Direitos protegidos, Capítulo II - Direitos Civis e Políticos; Artigo $4^{\circ}$ - Direito 
à vida, que tem seis itens, informa em seu primeiro que: "1. Toda pessoa tem direito de que se respeite sua vida. Esse direito deve ser protegido pela lei e, em geral, desde o momento da concepção. Ninguém pode ser privado da vida arbitrariamente" (CONVENÇÃO AMERICANA DE DIREITOS HUMANOS, 1969, p.2).

Assim como na Convenção Americana de Direitos Humanos, também está na Constituição Federal do Brasil, no caput do seu artigo $5^{\circ}$ a inviolabilidade do direito à vida e a criminalização parcial do aborto nos dois casos permitidos por lei são questionáveis. Segundo a Constituição Federal do Brasil:

Art. $5^{\circ}$. Todos são iguais perante a lei, sem distinção de qualquer natureza, garantindo-se aos brasileiros e aos estrangeiros residentes no País a inviolabilidade do direito à vida, à liberdade, à igualdade, à segurança e à propriedade, nos termos seguintes (...). (BRASIL, 1988, s/p)

A luta pela descriminalização do aborto e até mesmo a legitimação daquilo que é permitido à sua prática, esbarra em legislações como já mencionados, como por exemplo, o Código Civil, Estatuto da Criança e do Adolescente e até a própria Constituição, porque essa como as outras garante o direito à vida de todos, entretanto os incisos I e II do artigo 128 do Código Penal sustenta o contrário sobre esse direito.

Outro acontecimento que trouxe esse embate à tona ocorreu em julho de 2004, quando o Ministro relator, Marco Aurélio de Mello, do Supremo Tribunal Federal, expediu liminar aprovando a ação de descumprimento de preceito fundamental $n{ }^{\circ}$ 54/2004. Destarte, a liminar concedeu autorização para interrupção da gravidez nos casos de anencefalia. A aprovação vigorou por três meses e nesse período algumas mulheres se beneficiaram da decisão até ser revogada, porque o Supremo Federal decide voltar novamente a considerar crime nesse caso.

Além do assunto anencefalia gerar pela primeira vez uma questão de âmbito político ético nacional, por ser pauta de discussão no Supremo Tribunal Federal e mobilizar o Senado e Congresso, ele trouxe alguns desafios ${ }^{11}$. De acordo com Diniz (2008), essa liminar do ministro Mello, que autorizava mulheres grávidas de fetos com

\footnotetext{
${ }^{11}$ Ver o artigo: DINIZ, Débora. Anencefalia: Ciência e Estado Laico. CFEMEA - Centro Feminista de Estudos e Assessoria, 2008.
} 

após o parto" (Diniz, 2008, s/p).

Porém, esse debate foi bastante conflitivo, pois adentrou questões constitucionais, como a discutida no primeiro capítulo desta dissertação, conflitos de leis no espaço legislativo entre o Código Penal e a Constituição. É ainda importante sublinhar que diferentemente de outros países católicos que, entre os anos 1980 e 1990, experimentaram reformas constitucionais, a Constituição Brasileira de 1988 não adotou o princípio de respeito à vida desde a concepção. Em 1995 foi mais uma vez debatida e derrotada a proposta de emenda constitucional que visava a incluir este princípio no preâmbulo da Constituição (FREITAS, 2011, p. 10).

$\mathrm{Na}$ época o ministro preferia não falar em aborto, pois segundo ele existe um consenso médico de que em todos os casos de anencefalia há óbito do feto no período neonatal. Porém, com as pressões advindas dos setores contra o direito ao aborto e todo o embate causado pela liminar, o ministro decidiu convocar uma audiência pública antes do julgamento final no STF. Segundo Faria (2005), a primeira audiência pública nos 194 anos de existência do Tribunal. A alegação de setores tanto da área médica, jurídica, política, que enfim são contra o aborto, é que a liminar, na prática, abriria caminho para o extermínio de fetos com deficiências. Um argumento aparentemente confuso e sem fundamento em um contexto das tecnologias de reprodução assistida, em que se escolhe o sexo do bebê e outras características físicas, além de que somente em caso de acefalia com laudo comprovado médico, existiria o direito de aborto, zelando pelo bem-estar da mulher, evitando o sofrimento físico e psicológico de gerar um ser morto. (FARIA, 2005)

Todavia, esta decisão foi revogada em 20 de outubro do mesmo ano pelo plenário do Tribunal. Portanto, apesar da cassação da liminar, o aborto em casos de anencefalia extrapolou os limites da Medicina e do Direito, sendo atualmente uma questão política de maior importância, não somente porque o Brasil é o quarto país do mundo em partos de fetos com anencefalia, ou porque mostra toda a luta na esfera legal, mas porque, 
principalmente, trata-se de um tema do âmbito dos direitos reprodutivos, julgado e visto como uma questão de direitos humanos. (DINIZ, 2008).

Observa-se que em meio a esse "cabo de guerra" que o tema aborto proporcionou, entre os anos de 2004 e 2005 algumas oportunidades de reforma legal e jurídica foram ocasionadas possibilitando um debate de maneira mais ampla no país. Isto foi possível por duas vias: o debate vivenciado por meio do Ministro Marco Aurélio Mello sobre antecipação terapêutica do parto nos casos de anencefalia e o processo político que resultou na apresentação de uma proposta de revisão legislativa que pune a prática voluntária de interromper uma gravidez formulado então pela Comissão Tripartite. Essa comissão (formada por representantes do Legislativo, do Executivo e da sociedade civil organizada), por meio da Ministra Nilcéa Freire, entregou a proposta de lei no dia 28 de dezembro de 2005 que propõe a descriminalização do aborto no Brasil para ser encaminhado ao Congresso Nacional. Essa proposta de lei prevê a descriminalização do aborto até a $12^{\mathrm{a}}$ semana de gestação ou em qualquer idade gestacional quando a gravidez implica risco de vida à mulher ou em caso de má-formação fetal incompatível com a vida (CENTRO FEMINISTA DE ESTUDOS E ASSESSORIA, 2006).

Essa proposta normativa do governo que consagrava a prática do aborto como um direito inalienável de toda mulher, visando assim a sua total legalidade, teve o recuo por parte do Executivo, devido às pressões muito grandes da oposição pró-vida e da CNBB. Assim, o texto da Comissão Tripartite foi entregue para a deputada Jandira Feghali que em 2007, proveu o PL 1135/1991 de uma nova redação, incorporando o conteúdo do projeto citado acima da Comissão Tripartite, que foi posto em debate em audiências públicas $^{12}$, nas quais o Executivo teve uma presença tímida. O projeto de lei 1135 “aguarda votação de recurso para ser apreciado pelo Plenário da Câmara Federal. Mas seu texto não coincide com o texto original proposto pela Comissão Tripartite" (FREITAS, 2011, p.13). O texto, devido às modificação que sofreu, dadas pelas negociações entre os

\footnotetext{
12 A primeira audiência, realizada dia 12 de agosto de 2009, contou entre outros, com presença do ministro da Defesa Nelson Jobim, ex-presidente do Tribunal Superior Eleitoral. A segunda audiência, realizada dia 20 de agosto de 2009, contou, entre outros, com a presença da ministra da Secretaria Especial de Políticas para as Mulheres, Nilcéa Freire. Neste mesmo dia, a ministra, acompanhada de integrantes da Comissão Tripartite reuniu-se com o relator da CCT, Senador Eduardo Azeredo, solicitando o apoio deste para as demandas das mulheres (SECRETARIA DE POLÍTICAS PARA MULHRES, 2009, p.20).
} 
Em 2007, exatamente às vésperas da visita do Papa, mais uma vez a discussão que envolve setores governamentais e uma possível manutenção da proibição da legalidade do aborto aparece. O ministro da saúde na época, José Gomes Temporão, defendia a descriminalização do aborto, além de propor em 2008 um plebiscito, no qual a sociedade iria decidir pela legalização ou não do aborto no Brasil. De acordo com Diniz (2007, s/p ) “pela primeira vez um Ministro da Saúde posicionou-se favorável à mudança da legislação brasileira sobre aborto. A tese do Ministro José Gomes Temporão é simples: aborto é uma questão de saúde pública."

Em 2006, o movimento feminista fez 40 anos (CEFEMEA, 2009), mas apesar da luta que envolve o aborto ser uma batalha antiga, ainda é um caminho a ser conquistado. Um luta representativa no campo dos direitos humanos e no direito à saúde e autonomia reprodutiva feminina. Declarações como de José Gomes Temporão, Ministro da Saúde, entre os anos de 2007 e 2011 mostram que um "deslocamento do debate do campo moral para o da saúde pública provoca uma redefinição nos termos argumentativos que dominam o debate brasileiro nos últimos trinta anos". (DINIZ, 2007, s.p). Observa-se que as feministas vêm realizando o deslocamento desde as conferências do Cario e Pequim, a inflexão importante tenha sido um ministro de Estado dizer que o aborto inseguro devido a sua ilegalidade é uma questão de saúde pública.

A trajetória dos projetos de lei e suas datas de tramitações revelam um difícil manejo existente para discutir o aborto no âmbito legal. Segundo Diniz (2001), de 1949 a 2001, na Câmara Federal foram apresentados 23 projetos de lei sobre o aborto. Em 2008, já constam nos arquivos da Câmara dos Deputados, 61 Projetos de Lei (PLs) que tratam da temática do aborto desde o último ano da década de 40 (AMARAL, 2008).

Já nos anos de 2007 e 2008 "foram apresentados 12 PLs contrários e apenas um favorável ao aborto" e que o “PL 1.135/91, de autoria de Eduardo Jorge e Sandra Starling, 
Todavia, o aborto em casos de anencefalia gerou uma grande disputa judiciária, até que em abril de 2012, o Supremo Tribunal Federal autorizou a interrupção da gravidez em caso de fetos anencefálicos (sem cérebro) sendo dessa forma aprovada e regulamentada pelo Conselho Federal de Medicina. A decisão foi publicada pelo Diário Oficial em maio, com critérios definidos pelo Conselho Federal de Medicina, cabendo assim à gestante decidir se quer ou não manter a gravidez.

Recentemente, o questionamento sobre a ilegalidade da prática abortiva entrou em pauta novamente na esfera legal, em 2013, com o projeto de lei 478/2007. Tal PL denominado Estatuto do Nascituro, atualmente em tramitação na CCJ (Comissão de Constituição, Justiça e Cidadania) da Câmara dos Deputados tem como autores Luiz Bassuma e Miguel Martini, defensores do direito de todos à vida garantido pelo Estado, independentemente das circunstâncias proporcionadas à concepção de um novo indivíduo, mesmo esse sendo gerado por um estupro, que neste caso a prática abortiva é garantida por lei no artigo 128, inciso II. É no artigo13 do projeto de lei 478/2007 que a proposta pode virar uma futura criação de uma "bolsa estupro", uma pensão mensal de um salário mínimo para a mãe vítima de estupro. ${ }^{13}$

Aqueles que se posicionam contra a PL do Estatuto do Nascituro vêem a proposta como um retrocesso que fere vários princípios tanto dos direitos humanos como da laicidade do Estado, além dos direitos das mulheres quanto à autonomia dos seus corpos de querer ou não interromper uma gravidez indesejada. Entre os opositores da proposta estão as organizações feministas como Centro latino Americano em Sexualidade e Direitos Humanos - CLAM, Centro Feminista de Estudos e Assessoria - CFEMEA entre

\footnotetext{
13 Art. 13. O nascituro concebido em decorrência de estupro terá assegurado os seguintes direitos, ressalvados o disposto no Art. 128 do Código Penal Brasileiro: I - direito à assistência pré-natal, com acompanhamento psicológico da mãe; II - direito de ser encaminhado à adoção, caso a mãe assim o deseje. $\S 1^{\circ}$ Identificado o genitor do nascituro ou da criança já nascida, será este responsável por pensão alimentícia nos termos da lei. $\S 2^{\circ} \mathrm{Na}$ hipótese de a mãe vítima de estupro não dispor de meios econômicos suficientes para cuidar da vida, da saúde do desenvolvimento e da educação da criança, o Estado arcará com os custos respectivos até que venha a ser identificado e responsabilizado por pensão o genitor ou venha a ser adotada a criança, se assim for da vontade da mãe. (BASSUMA; MARTINI, 2013, p.3).
} 
outras e a antropóloga Débora Diniz que vê o projeto de lei como uma violenta pressão histórica e social imposta ao gênero feminino e repleto de equívocos:

o Estatuto do Nascituro é mais um ato de terror, só que agora do Estado contra elas. Além de ter sido vítima do violentador, a menina se descreverá como mulher violentada pelo Estado, que reconhece os direitos de um espectro de pessoa como superiores à própria existência. (DINIZ, 2013, s.p)

A progressão dos números de projetos de lei ao longo dos anos, os embates acirrados pelos grupos "pró-descriminalização do aborto" e "contra-aborto" dentro do parlamento e da influência indireta da sociedade civil proporcionam uma clara visibilidade de como o assunto dentro da esfera legal, mas não só nela, é polêmico. Promover o debate sobre o aborto como propôs este trabalho é fornecer uma análise mais atenta às concepções de vida, mulher, cidadania, direitos humanos que podem ser extraídos da leitura dos projetos de lei aqui elencados. Essa análise, a partir de uma discussão que vai além de opiniões restritas a serem a favor ou contra a prática abortiva, enriquece a compreensão sobre o que está em jogo nesse debate e significa mudar a pauta sobre o aborto de uma questão moral e religiosa para uma questão de saúde pública e de direitos humanos. Perceber também os desafios que se colocam para o feminismo, para a sociedade civil e para o Estado como no desenvolvimento de sociedades verdadeiramente democráticas, justas e libertárias e menos marcadas pelas desigualdades de gênero naquilo que toca a criminalização e a descriminalização do aborto.

\section{Referências}

AMARAL, Fernanda Pattaro. O Estado Brasileiro e a questão do aborto: a influência das falas parlamentares e religiosas na discussão de políticas públicas. In: Fazendo Gênero 8 Corpo, Violência e Poder, Florianópolis, de 25 a 28 de agosto de 2008.

Anais...Florianópolis, 2008. Disponível em < http://www.fazendogenero.ufsc.br/8/sts/ST40/Fernanda_Pattaro_Amaral_40.pdf>. Acesso em: 25 março 2014 .

BASUMA, Luiz; MARTINI, Miguel. 478/2007. Brasília, 2013. 
BRASIL. Presidência da República, Governo Luiz Inácio Lula da Silva. 2009. Programa Nacional de Direitos Humanos - PNDH III. Brasília: Presidência da República, Secretaria de Comunicação Social, Ministério da Justiça. Disponível em:<

http://portal.mj.gov.br/sedh/pndh3/pndh3.pdf>. Acesso em 10 out. 2011.

BRASIL. Presidência da República, Governo Luiz Inácio Lula da Silva. 2009.. Direitos sexuais e direitos reprodutivos: uma prioridade do governo/Ministério da Saúde, Secretaria de Atenção à Saúde, Departamento de Ações Programáticas Estratégicas - Brasília: Ministério da Saúde, 2005.

BRASIL. Presidência da República. Secretaria Especial de Políticas para as Mulheres. Plano Nacional de Políticas para as Mulheres. 2004. Disponível em:<

http://200.130.7.5/spmu/docs/Plano\%20Nacional\%20Politicas\%20Mulheres.pdf $>$. Acesso em 10 abr. 2011.

BRASIL. Presidência da República. Secretaria Especial de Políticas para as Mulheres. Plano Nacional de Políticas para as Mulheres II. 2008. Disponível em:<

http://bvsms.saude.gov.br/bvs/publicacoes/II_PNPM.pdf>. Acesso em 10 abr. 2011.

BRASIL. Novo Código Civil. 2010 a. Disponível em:<

http://www.jucepa.pa.gov.br/downloads/docs/pdf/Novo_codigo_civil.pdf>. Acesso em 15 mai. 2011.

BRASIL. Estatuto da Criança e do Adolescente. Lei Federal n 8069, de 13 de julho de 1990. Disponível em: < http://www.franciscanos.org.br/v3/sefras/noticias/pdf/eca.pdf >. Acesso em mai. 2011.

BRASIL. Código Penal. 48. ed. São Paulo: Saraiva, 2010.

BRASIL. Ministério Da Saúde. Norma técnica de atenção aos agravos da violência sexual contra mulheres e adolescentes. Brasília, 2002.

BRASIL. Senado Federal. Proposições legislativas sobre questões femininas no Parlamento Brasileiro, 1826-2004. Brasília : Senado Federal, Comissão Temporária do Ano da Mulher : Senado Federal, Subsecretaria de Arquivo, 2004.

CATÓLICAS PELO DIREITO DE DECIDIR. Quem somos. Disponível em: <http://catolicasonline.org.br/QuemSomos.aspx>. Acesso em: 02 fev. 2010.CENTRO 
FEMINISTA DE ESTUDO E ASSESSORIA. Os direitos das mulheres na legislação brasileira pós-constituinte. Brasília: LetrasLivres, 2006.

CENTRO FEMINISTA DE ESTUDO E ASSESSORIA. Os direitos das mulheres na legislação brasileira pós-constituinte. Brasília: LetrasLivres, 2006.

CENTRO FEMINISTA DE ESTUDO E ASSESSORIA. . Direitos Reprodutivos em Pauta: Projeto de Lei 1135/91: um relato do CFEMEA. Disponível em:

<http://www.cfemea.org.br/noticias/detalhes.asp?IDNoticia=732>. Acesso em: 20 nov. 2010.

CENTRO FEMINISTA DE ESTUDO E ASSESSORIA. . Aborto: debater é legal. 03 de Maio de 2011. Disponível em: <

http://www.cfemea.org.br/index.php?option=com_content\&view=article\&id=3535:aborto -debater-e-legal\&catid=219:noticias-e-eventos\&ltemid=154>. Acesso em: 12 maio 2011.

CENTRO FEMINISTA DE ESTUDO E ASSESSORIA. . Carta aberta em favor dos direitos sexuais e reprodutivos das mulheres brasileiras. 15 nov. 2007 b. Disponível em:<

http://www.cfemea.org.br/index.php?option=com_content\&view=article\&id=2086\&ltemi $\mathrm{d}=145>$. Acesso em: 10 maio 2011.

CENTRO FEMINISTA DE ESTUDO E ASSESSORIA. . Proposições relacionadas com aborto que estão tramitando no Congresso Nacional. Jun. 2005 b. Disponível em: < http://www.cfemea.org.br/index.php?option=com_content\&view=article\&id=1074:propo sicoes-relacionadas-com-aborto-que-estao-tramitando-no-congressonacional\&catid=129:numero-145-junho-de-2005\&ltemid=129>. Acesso em: 10 jun. 2011.

CENTRO FEMINISTA DE ESTUDO E ASSESSORIA. . Direitos sexuais e reprodutivos em risco. 2007 a. Disponível em: < http://www.cfemea.org.br/>. Acesso em: 20 jun. 2010.

CENTRO FEMINISTA DE ESTUDO E ASSESSORIA. . Mais uma morte evitável de gestante no Brasil, 2010. Disponível em: <

http://www.cfemea.org.br/index.php?option=com_content\&view=article\&id=2307:maisuma-morte-evitavel-de-gestante-no-brasil\&catid=219:noticias-e-eventos\&ltemid=154>. Acesso em: 10 jun. 2011.

CENTRO FEMINISTA DE ESTUDO E ASSESSORIA. . Projeto de Lei 1135/91: um relato do CFEMEA. 2008. a Disponível em:<

http://www.cfemea.org.br/index.php?option=com_content\&view=article\&id=2704:projet o-de-lei-1135-91-um-relato-do-cfemea\&catid=219:noticias-e-eventos\&ltemid=154>. Acesso em 9 mai. 2011. 
CENTRO FEMINISTA DE ESTUDO E ASSESSORIA. . 05 a 09 de dezembro de 2005 a. Disponível em:

<http://www.cfemea.org.br/index.php?option=com_content\&view=article\&id=2458:proje to-de-enfrentamento-da-violencia-domestica-contra-as-mulheres-continua-em-discussaona-camara\&catid=384:a-semana-no-congresso\&ltemid=175.>. Acesso em 17 jun. 2011.

CENTRO FEMINISTA DE ESTUDO E ASSESSORIA. Mulheres reúnem-se pelo fim da violência no DF. 2009. Disponível em: <

http://www.cfemea.org.br/index.php?option=com_content\&view=article\&id=2240\&ltemi $d=151>$. Acesso em mar. 2011.

CENTRO FEMINISTA DE ESTUDO E ASSESSORIA. . Participação Política das Mulheres e Gestão em Política de Gênero. Disponível em:

<http://www.cfemea.org.br/index.php?option=com_content\&view=article\&id=1575:partic ipacao-politica-das-mulheres-e-gestao-em-politica-de-genero\&catid=212:artigos-etextos\&Itemid=146>. Acesso em: 20 jun. 2010.

CENTRO FEMINISTA DE ESTUDO E ASSESSORIA. . Religiosos políticos: mentes conservadoras desafiam o caráter laico do Estado. 2008. . Disponível em: < http://www.cfemea.org.br/index.php?option=com_content\&view=article\&id=1290:religio sos-politicos-mentes-conservadoras-desafiam-o-carater-laico-doestado\&catid=142:numero-158-dezembro-de-2008-especial\&Itemid=129>. Acesso em: 10. Mar. 2010.

CENTRO FEMINISTA DE ESTUDO E ASSESSORIA. . Um espelho das moralidades: o debate sobre aborto no Congresso Nacional brasileiro. SérieAnis 23, Brasília, LetrasLivres, 1-3, novembro, 2001.

CONGESSO EM FOCO. Aborto ficará fora da pauta do Congresso em 2010. Disponível em: http://congressoemfoco.uol.com.br/noticia.asp?cod_publicacao=31420\&cod_canal=1. Acesso em: 10 nov. 2010.

CONSELHO FEDERAL DE MEDICINA. Processo consulta $n^{\circ} 2.862 / 89 P C / C F M / n^{\circ}$ 01/1990. Disponível em:< http://www.portalmedico.org.br/pareceres/cfm/1990/1_1990.htm>. Acesso em: 16 jun. 2010.

CONVENÇÃO AMERICANA DE DIREITOS HUAMANOS. Pacto de San José. San José de Costa Rica, em 22 de novembro de 1969. Disponível em: < http://www.tjpe.gov.br/coordvinf/arquivos/pactoSanJose.pdf>. Acesso em 30 mai. 2011.

DECLARAÇÃO e plataforma de ação da IV Conferência Mundial Sobre a Mulher. Pequim, 1995. Disponível em: <http://bvsms.saude.gov.br/bvs/publicacoes/declaracao_4_conferencia_mundial_mulher. pdf $>$.Acesso em: 4 jun. 2011 
DINIZ, Débora. Anencefalia: ciência e estado laico. In: CFEMEA - Centro Feminista de Estudos e Assessoria, 2008.

DINIZ, Débora. Aborto e saúde pública no Brasil. 1992 Editorial. Cad. Saúde Pública, Rio de Janeiro, v.23, n.9, p.1992-1993, set, 2007.

DINIZ, Débora. O Estatuto do nascituro e o terror. Entrevista cedida a Ana Paula Galli. In: Centro Brasileiro de Estudos de Saúde., Disponível em:

http://www.cebes.org.br/internaEditoria.. spp?idConteudo=4428\&idSubCategoria=30. Acesso em 14 jun. 2013.

FARIA, Nalu. Exclusão e mulheres na América Latina. In: SOF-SEMPREVIVA ORGANIZAÇÃO FEMINISTA. Feminismo e luta das mulheres: análise e debates. São Paulo: SOF, 2005.

FREITAS, Ângela. Aborto: guia para profissionais de comunicação. / Coordenadora Paula Viana; Colaboração Beatriz Galli [et. al.]. Recife: Grupo Curumim, 2011.

GODINHO, Tatau. São Paulo. Prefeitura Municipal. Coordenadoria Especial da Mulher; Secretaria do Governo Municipal. Políticas públicas e igualdade de gênero / Tatau Godinho (org.). Maria Lúcia da Silveira (org.). - São Paulo: Coordenadoria Especial da Mulher, 2004 .

GONÇALVES, Tamara Amoroso; LAPA, Thaís de Souza. Aborto e religião nos tribunais brasileiros. Coordenação de Tamara Amoroso Gonçalves. São Paulo: Instituto para a Promoção da Equidade, 2008.

GRAÇA, Eliane Magalhães; MALAGUTI, Mirelli; VIEIRA, Célia Maria Farias. Orçamento e gênero: A luta pela igualdade: os oito anos de governo FHC. Disponível em:<http://www.cfemea.org.br/index.php?option=comarticle-luta-pelaigualdade\&catid=2. Acesso em: 20 jul. 2010.

JORGE, Eduardo; STARLING, Sandra. PL1135/1991. Brasília, 1991.

ORGANIZAÇÃO MUNDIAL DA SAÚDE. Aborto espontâneo e provocado. Genebra, 1990.

PEDRO, Joana Maria. Práticas proibidas: práticas costumeiras de aborto e infanticídio no século XX. Florianópolis: Cidade Futura, 2003.

PERROT, Michelle; DUBY, Georges. História das mulheres no ocidente. Porto: Afrontamento, 1991.

PIMENTEL, Silvia. Aborto: um direito da mulher. Lua Nova: Revista de Cultura e Política. Pensando o Brasil desafio constituinte. v..2 n.2 São Paulo Se. 1985.p.00-0o 
PRIORE, Mary Del. (Org.). História das mulheres no Brasil. São Paulo: Contexto, 2001.

PINTO, Céli Regina J. Uma história do feminismo no Brasil. São Paulo: Perseu Abramo, 2003.

REDE FEMINISTA DE SAÚDE. Dossiês sobre saúde da mulher e direitos reprodutivos. São Paulo, 2001.

ROCHA, Maria Isabel Baltar da. A Questão do aborto no legislativo brasileiro: uma visão geral dos anos 90 e da década atual. In: Encontro Nacional de Estudos Populacionais, XVI, Caxambu-MG Anais. Caxambu:[s.n], 2008.

SCAVONE, Lucila. Políticas feministas do aborto. Revista Estudos Feminista, Florianópolis, v..16, n.2, p.675-680. Ago, 2008.

SCAVONE, Lucila.. Direitos reprodutivos, políticas de saúde e gênero. Estudos de Sociologia, Araraquara, v. 5, n. 9, p. 141-158, 2000.

SCHERER, Odilo Pedro. Um estatuto para os nascituros. In: Conferência Nacional dos Bispos do Brasil, 2010. Disponível em: < http://www.cnbb.org.br/outros/cardeal-odilopedro-scherer/4914-um-estatuto-para-os-nascituros>. Acesso em: 10. Nov. 2010.

SECRETARIA DE POLTICAS PARA MULHRES. Comissão Tripartite para revisão da lei 9.504/1997: relatório final. Brasília, 2009. 
Universidade do Estado de Santa Catarina - UDESC Programa de Pós-Graduação em História - PPGH Revista Tempo e Argumento Volume 06 - Número 11 - Ano 2014 tempoeargumento@gmail.com 